М.С.Саякпаева ${ }^{1}$, В.Дж.Насирова ${ }^{1}$, Н.Шаршенбек к. ${ }^{1}$

${ }^{1}$ КГУСТА им. Н.Исанова, Бишкек, Кыргызская Республика

M.S. Sayakpaeva ${ }^{1}$, V.Dzh. Nasirova ${ }^{1}$, N.Sharshenbek k. ${ }^{1}$

${ }^{1}$ KSUCTA n.a. N. Isanov, Bishkek, Kyrgyz Republic

e-mail: smairam63@gmail.com nasirova.venera@cloud.com naska_802@mail.ru

\title{
HOW TO DEVELOP READING AND READING COMPREHENSION IN ENGLISH
}

\section{АНГЛИС ТИЛИНДЕ ТУШУНУП ОКУУНУ КАНТИП ӨНУКТУРСӨ БОЛОТ}

\section{КАК РАЗВИТЬ ЧТЕНИЕ И ПОНИМАНИЕ ПРОЧИТАННОГО НА АНГЛИЙСКОМ ЯЗЫКЕ}

Бул макаладаанглис тилинде окууну жана түшүнүҮнҮ кантип өркүндөтүүгөболот деген суроолого жоопторжана кеңештер каралган.

өзөк сөздөр: чеберчилиги, ун чьгаруу, окуу, жаттоо, үйрөнүҮ, тил, тил бурмалоо, эркин суйлөө, мылшыктыруу, үйрөтҮY.

В этой статье представлены ответы и советь о том, как улучшить чтение и понимание на английском языке.

Ключевые слова: умение, громко, читать, запомнить, учить, язык, скороговорки, бегло, тренировать, обучать.

Answers and tips on how to develop reading and reading comprehension in English are considered in this article.

Key words: skill, loud, read, remember, learn, tongue, twisters, fluent, train, educate.

Reading is a set of practices and procedures for working with a written text and the process of working with a text directly, aimed at extracting information from it, at the perception of the text and its understanding. In a broad sense - the process of extracting information also from any symbolic system (Braille symbols, musical notation, etc.) [1]

Reading makes the human brain work, expands a person's horizons, increases vocabulary, enriches the inner world, trains thinking. Reading skill is a complex of skills and abilities. It develops the ability to understand the meaning of the text, read words correctly, read expressively, focusing on punctuation marks and content, not forgetting about the pace of reading.

We read in order to:

1) Receive detailed information on the issue of interest to us;

2) Find errors in the text;

3) Do your homework;

4) Have fun;

5) Understand whether this text will help to obtain the necessary information;

6) Understand the main idea or determine what the text is about;

7) Find answers to specific questions;

8) Learn to quickly read aloud in compliance with basic pronunciation norms;

9) Write a similar text yourself;

10) Prepare an oral or written report;

11) Find the studied grammatical phenomenon in the text and use it as an example of its use;

12) Find new words and guess their meaning from the context; 
13) Perform a test / control task, etc...;

14) Learn something new;

15) Find deliberately biased information, and then appeal to it in oral or written controversy:

The role of reading, including in a foreign language, is extremely important in the modern world. It is included in the sphere of human communicative and social activities and plays a huge role in the modern world, rich in various kinds of information.

At the present stage of development of society, the role of reading in English is clearly increasing given that English increases your chances of getting a good job in a multinational company within your home country or for finding work abroad. It is the language of international communication, the media and the internet. Learning English is also important for socializing and entertainment. One of the ways to learn English is by reading.

Reading in English began to be perceived as one of the main goals of teaching - a source of obtaining new intellectual and aesthetic information, which will noticeably enrich the student's personality if the learning process develops in him the ability and habit to use this source.

Reading in English will allow you to learn news from world sources and receive important information from your field of activity. It is necessary for every educated person, for good specialist to know English. To learn the English language is not an easy thing. It is considered the hardest thing in English to learn to read correctly.

Without reading in English, you are unlikely to be able to learn a foreign language - this is the tool that will help you extract all the necessary information from teaching texts. This is a kind of visual support for thinking - it is known that for better learning it is necessary to reinforce the material with visual images and text all the time.

These tips will help you to learn English:

- Learn the alphabet, vowel reading rules, learn to spell.

- Practice your pronunciation Practice sounds that are unusual for your language. You should listen to the dialogues and monologues of native speakers.

- It is necessary to remember how certain letters and letter combinations are read.

- Learn to write and read the transcription of sounds in English.

- Learn English tongue twisters and poems. Tongue twisters help you practice pronunciation of difficult sounds. Poems enrich the vocabulary.

- Constantly practice reading every day, read short stories.

We'll also talk about reading comprehension in this article.

Reading comprehension means how much you understand what you are reading. Even if you read books in English every week, it will not help you in learning if you don't know what the words on the pages are talking about.

To improve you reading skills, start reading from a popular science magazine with short articles. Read native-speaking authors, use a dictionary. Read English-language writers: Mark Twain, Clive Staples Lewis, Rudyard Kipling and others. The language of these books is simple and understandable.

One of the steps to improve your reading comprehension is to read fluently. The goal of a fluent reading is to grasp the main points of the text, without stopping. Regular reading in English allows you to replenish your vocabulary, also to observe the practical application of grammatical structures in ready-made texts on the details.

If you have an audio book, try to read with the narrator, it makes you read faster and will improve your fluency. Another great way to read fluently is to watch the English films with subtitles. You will be able to read the words and hear a native speaker pronounce them.

After you can read faster, it is time to slow down. Stop paying attention to reading speed and start thinking about its meaning. One great way to slow down is to read aloud. Reading loudly external dubbing of graphic text. Reading aloud, you will better understand the meaning of the text, memorize new words and text structures. The person is less distracted, his attention is completely focused on the text. 
Loud expressive reading allows you to develop mental and speech skills at any age. When you read the text aloud several areas of the brain work (the visual, auditory and motor cortex), the chances of understanding and remembering what we read naturally increase.

You can read out aloud with another person one paragraph at a time. After each paragraph, discuss what you read.

Another useful technique of reading is reading to oneself (silent reading). In our practical life, we mostly read silently. What are we doing in a cafe or restaurant? We read the menu in silence. We silently read many instructions in transport, in hospitals and in various public places. We do it naturally. Why? We do not want to disturb our neighbors. We just want to know the message from the written words. Reading quietly has a higher purpose, however, that goes beyond reluctance to annoy our neighbor

Silent reading helps us read faster. It helps us make faster connection between words and it gives us the silence we need to concentrate and process information. Silent reading takes place without external graphic text; aims only to obtain information. This is real reading as a form of speech activity.

All modern programs distinguish three main types or reading skills. To read effectively in a foreign language, you need to develop certain skills, for example:

- Skimming-you should define the main idea of the text without details.

- Intensive reading is used for understanding the content and the meaning of the text.

- Scanning-you should find specific information in the text.

The choice of the type of reading depends on the genre of the text. For intensive reading, you can use science, fiction or journalistic genre. For skimming, use authentic materials that show the life and culture of English-speaking countries. For scanning, you should choose for some useful information.

Before you can start reading, pay attention for this information:

- Take some time to prepare.

- You should not be distracted by extraneous affairs.

- Define a purpose of the reading, what you should find in the text.

- Look at the title of the text and try to guess what the text might be about.

- Skim through the text, pay attention to the headings, words and illustrations.

- Try to remember what you have already known about the topic and author.

While reading:

- Consider what you read after each paragraph.

- Consider if you agree with the ideas, characters or facts.

- If you do not understand the meaning of some sentences new words, write them down and find out their meanings after reading.

After reading:

- Think a little about what you have read

- Links in the text to what you already know, what you read before.

- Read the text again, trying to find answers to your questions: how? why? where from? where? for what reason?

- Try talking with another person.

- Make graphic: Create a chart showing your understanding before and after reading.

- After reading, you can use the questions below to help you think about what you did and what you didn't understand:

- What was the text about?

- What is the most important thing that happened in the text?

- Did anything confuse you?

- Did anything surprise you?

- Are there parts that you did not understand? 
- Try to retell the text.

Exercises for teaching reading are divided into tasks and exercises before reading the text and exercises to control comprehension. Before reading the text, tasks can be given to mobilize the attention of students, to highlight the most important points, for example:

1.Read the text or part of the text and tell what the main ideas are contained in it and write what you learned new or just interesting by reading this text

2. Read the text, so that later you could tell about the characters, their actions, about the events described in the text.

3. Before reading the text, preparatory exercises may also be given.

4. After reading the text, answer the questions about the content of the text, conveying the main content, drafting dialogues on the subject of the text.

Tasks and types of reading:

Tasks should transform the text into a specific exercise and aim the student at obtaining the final result, a certain depth and accuracy of understanding (for example, "Read and reveal the main idea", "Reading, identify, find ...", etc.).

Pre-text stage purpose:

- Purpose: Define / formulate a speech problem for the first reading.

- Create the necessary level of motivation among students, arouse interest in the text.

- To activate the background knowledge on the subject of the text.

- Remove the difficulties of language, speech, content.

Pre-text stage Exercises and tasks:

- Working with the heading. Define: topic of the text, a list of the problems raised in it, keywords and phrases.

- Use of associations associated with the name of the author: who will be the main character? Where and at what time can the action take place?

Pre-text stage Exercises and assignments:

- Assumptions about the topic of the text based on illustrations: acquaintance with new vocabulary and identification of related topics / issues, reading questions / statements on the text and determining its subject, answer the proposed questions before reading the text.

Text stage purpose:

- To control the degree of formation of various language skills and speech skills.

- Continue building relevant skills and abilities.

Text stage Exercises and tasks:

1. Find / select / read / connect / insert:

- Answers to the proposed questions;

- Verify if information is true / false;

- A suitable heading for paragraphs;

- A sentence missing in the text;

- A description of the appearance / place of the event / attitude of someone to something.

Text stage exercises and tasks: 1 . Guess

- About the meaning of a word or words in context;

- Which of the proposed translations / which definition of the word most accurately reflects its meaning in this context;

- How events will develop in the next part of the text.

Post-text stage Purpose:

- To use the situation of the text as a linguistic / speech / content support for the development of skills in oral and written speech. 


\section{Conclusion: How to Develop English Reading Skills}

Reading in English will allow you to learn news from world sources and receive important information from your field of activity. English is the language of politics, diplomacy, science, technology, business, trade, sport and pop music.

It is necessary to read in English correctly (learn the alphabet, vowel reading rules, spelling, pronunciation, and remember the reading of letters and letter combinations). Focus on pronouncing each word carefully and correctly.

You should practice reading every day. You should read the text in whole phrases, not in separate words. Read short stories, learn tongue twisters, poems, enrich vocabulary). Find special time for reading. Get in the habit of reading at least a couple of pages a day (about 30 minutes every day). For training, choose only material of your level, where about $80 \%$ of the vocabulary is known.

Reading skills will lead to understanding the meaning of the text, read words correctly and expressively. At first, define the goal of reading, what you should find in the text (the main contents of the text or supporting details).

Use one types of reading techniques (skimming, intensive reading, scanning). Try to read faster and faster with each approach. To track your progress and measure your speed. And learn Sight Words - they'll speed you up.

Practice reading fluency, aloud and silent reading. Fluent reading leads to quick reading of the text. The purpose of reading aloud is the transmission of information obtained from the text. Reading to yourself will help you to focus on information.

The first effect of reading is vocabulary expansion. When you read the texts, you invariably come across the same words. Due to the repetitiveness of the vocabulary, you simply cannot help but remember it.

The second effect of reading is the subconscious assimilation of grammar. Words in the text are related to each other according to certain rules. You perceive these rules in their action, and not in an abstract form, as it is presented in textbooks.

The third effect of reading is the gradual restructuring of thinking. After all, you can consider a text as a sequence of words related to each other according to certain rules, but it can also be viewed as a stream of meanings and means of their expression.

You can read for fun anywhere. You can take a funny book on the bus, in bed or in the office and enjoy it. However, if you are reading to improve your reading comprehension in English, you need to focus and study.

\section{List of references:}

1. www.ru.m.wikipedia.org.

2. http::;//www.znanija.com/tasle8664652

3. http://www.fluentu.com/blog/english/how- to-imporo

4. http://www.Lingualeo.com/blog/

5. http://www.enguide.ua/magazine/english-rus

6. www.elc-schools.com 